\title{
Striving for Better Medical Education: the Simulation Approach
}

\author{
Boris E. Sakakushev1', Blagoi I. Marinov²,4, Penka P. Stefanova', Stefan St. Kostianev², \\ Evangelos K. Georgiou ${ }^{3,4}$ \\ ${ }^{1}$ Department of Propedeutics of Surgery, Faculty of Medicine, Medical University of Plovdiv, Plovdiv, Bulgaria \\ 2 Department of Pathophysiology, Faculty of Medicine, Medical University of Plovdiv, Plovdiv, Bulgaria \\ ${ }^{3}$ Medical Physics Lab-Simulation Center, Medical School, University of Athens, Athens, Greece \\ ${ }^{4}$ Medical Simulation Training Center, Medical University of Plovdiv, Plovdiv, Bulgaria
}

\section{Correspondence:}

Boris E. Sakakushev, Department of Propedeutics of Surgery, Faculty of Medicine, Medical University of Plovdiv, 66 Peshtersko Schosse St., 4002 Plovdiv, Bulgaria

E-mail: bsakakushev@gmail.com

Tel: +359 889716672

Blagoi I. Marinov, Department of Pathophysiology, Faculty of

Medicine, Medical University of Plovdiv, 15A Vassil Aprilov Blvd., 4002 Plovdiv, Bulgaria

e-mail: bmarinov@pathophysiology.info

Tel: +359 887567798

Received: 23 March 2017

Accepted: 18 Apr 2017

Published Online: 24 Apr 2017

Published: 27 June 2017

Key words: medical simulation, simulation-based training

Citation: Sakakushev BE, Marinov BI, Stefanova PP, Kostianev SS,

Georgiou EK. Striving for better medical education: the simulation approach.

Folia Medica 2017;59(2);123-131.

doi: 10.1515/folmed-2017-0039
Medical simulation is a rapidly expanding area within medical education due to advances in technology, significant reduction in training hours and increased procedural complexity. Simulation training aims to enhance patient safety through improved technical competency and eliminating human factors in a risk free environment. It is particularly applicable to a practical, procedure-orientated specialties.

Simulation can be useful for novice trainees, experienced clinicians (e.g. for revalidation) and team building. It has become a cornerstone in the delivery of medical education, being a paradigm shift in how doctors are educated and trained. Simulation must take a proactive position in the development of metric-based simulation curriculum, adoption of proficiency benchmarking definitions, and should not depend on the simulation platforms used.

Conversely, ingraining of poor practice may occur in the absence of adequate supervision, and equipment malfunction during the simulation can break the immersion and disrupt any learning that has occurred. Despite the presence of high technology, there is a substantial learning curve for both learners and facilitators. The technology of simulation continues to advance, offering devices capable of improved fidelity in virtual reality simulation, more sophisticated procedural practice and advanced patient simulators. Simulation-based training has also brought about paradigm shifts in the medical and surgical education arenas and ensured that the scope and impact of simulation will continue to broaden.

\section{BACKGROUND}

Medical disciplines such as surgery have had simulation training type models for centuries. These models have ranged from inanimate representations of the human body through to cadaveric dissections. All of them have been pioneered and developed for the purpose of improving medical knowledge and procedural skills.

What has changed over the last two decades is how these training devices are constructed and leveraged to deliver evidence-based training and assessment within a curriculum. ${ }^{1}$ With the recent advances in technology, there has been a rapid expansion in simulating many aspects of medical education, with increasing sophistication. Contemporary computer capabilities have enhanced the construction of complex anatomical and physiological systems programmed to respond to the inputs of the user. There have also been advances in manikins and devices to physically replicate the steps of performing complex procedures.

Simulation allows the deliberate practice of a skill to be undertaken completely or partially. Complex situations can be broken down into constituent parts 
reproducibly and each step rehearsed as many times as necessary to gain competence. The focus is on areas which the individual learner or team finds most challenging and can be applied to procedural skills as well as clinical scenarios. This can be done under the supervision of a mentor, teacher, or peer who should provide feedback (debriefing) on performance and guidance, including points to focus on at the next repetition. This feedback is critical to performance improvement. A consensus has been established that in education, delivering simulation alone has little or no effect on learning and may in fact encourage the acquisition and propagation of poor practice. ${ }^{2}$

In this review we describe what makes for a good medical simulation, how to ensure that the chosen simulation is effective, efficient and facilitates the acquisition of surgical and procedural skills.

\section{WHY SIMULATION?}

The new technologies disrupt the scenery of everyday medical practice. Their adoption is fast and challenging, therefore causing sudden and radical changes over a short time. The rate of change through the introduction of the new approaches and new technologies to the overall performance in medical practice had increased exponentially. Although this is affecting the medicine as a whole, it impacted worst on surgery and other procedural specialties, because the acquisition of their skills could only occur in a relatively specialized environment that only simulation can provide. Technology has not been the sole driver for simulation. Recently, quality and safety in health care and reduction in error has been the subject of intense focus, with the recognition that staff training has an important role for improving standards. In the European Union, working hours have been moderated for staff, resulting in a significant reduction in training hours and loss of continuity of care. ${ }^{3}$

Last but not least, simulation provides an objective assessment of performance and level of skills acquired. Although the assessment of skills has been left traditionally to the prerogative of the supervising consultant, new standardized assessment methodologies have been introduced and are a mandatory part of training and career progression. For all the reasons listed above, simulation may provide multiple benefits and therefore should be strongly recommended for adoption in routine practice, including the recommendation that "skills should be learned in a simulation setting prior to undertaking them on patients". ${ }^{4}$

The simulation approach is important because other procedural disciplines in medicine are confronting the same problems as surgery. For instance, an overview of the available literature pertaining to the use of simulation in bronchoscopy education, demonstrates how this limited yet valuable body of work lays a foundation for the future use of simulator-based bronchoscopy training. ${ }^{5}$

Given the pace of change in surgery today and a growing need to decrease variability in the delivery of health care to optimize quality while minimizing cost, surgeons need an "educational home" where they can return to retool intermittently throughout their career. Therefore the need for a robust educational structure to support practicing surgeons as well as for students and postgraduate trainees is needed and simulation can provide this. ${ }^{6}$

A comprehensive simulation center must fulfill the following requirements:

- A training program that has a clear end point which provides the facilities and opportunities for learning to meet the level of proficiency

- A deliberate practice training regimen is more commonly used which affords the opportunity for independent pacing of skill acquisition

- A coherent curriculum with appropriately sequenced learning material

- A variety of learning experiences (lecturers, seminars, small group teaching, e-learning, silicon models, virtual reality emulators, highfidelity virtual reality simulators, cadavers and real patients) to optimize learning availability;

- Formative and summative metric-based assessments to maximize the probability of learning.

\section{SIMULATOR TYPES}

One way to classify surgical simulators is based on the technology they use and are described as low- and high-tech simulators, while another way is based on the degree of their fidelity and evaluate characteristics like tactile and interaction feedbacks and visual clues. A summary of different types of simulators along with their advantages and disadvantages is presented in Table 1.

Low-tech simulators are not computer-driven and are either the synthetic models or the organic simulators comprising the human cadavers, the animal models and the harvested animal tissues, which are animal tissues attached to synthetic frames.

Synthetic models are:

- the bench top models designed to teach open 
Table 1. Surgical simulation training models

\begin{tabular}{|c|c|c|}
\hline Models & Advantages & Disadvantages \\
\hline Animals-Cadavers & $\begin{array}{l}\text { Realism } \\
\text { Complications }\end{array}$ & $\begin{array}{l}\text { Different anatomy } \\
\text { Cost } \\
\text { Moral issues }\end{array}$ \\
\hline Synthetic models - Towers & $\begin{array}{l}\text { Perfect for training into partial } \\
\text { steps of a procedure }\end{array}$ & $\begin{array}{l}\text { Only parts of a procedure } \\
\text { Expert presence required } \\
\text { A new setup each time }\end{array}$ \\
\hline VR/AR simulators & $\begin{array}{l}\text { Whole procedures available } \\
\text { Different difficulty levels } \\
\text { Expert presence not required }\end{array}$ & $\begin{array}{l}\text { Acquisition cost } \\
\text { Graphics realism ? } \\
\text { Force / haptic feedback ? }\end{array}$ \\
\hline
\end{tabular}

surgical procedures and include the tasks for knot-tying, fascia closure and suturing

- the video-box trainers or the tower trainers designed to teach minimally invasive procedures, which are typically portable, low cost, low maintenance and can be used repeatedly by multiple users. ${ }^{7}$

Video-box trainers include a box with a lid and holes cut on the lid for the trocar's insertion. A laparoscope inside the box is connected with digital camera and provides video output to monitor on which the trainees are watching their own movements, while performing the teaching task. Laparoscopic instruments such as graspers and scissors are inserted through the trocars into the box, where the tasks are taught. These inexpensive models are designed to develop hand-eye coordination and bimanual dexterity and can simulate a variety of techniques such as laparoscopic peg transfer, circle cutting, intracorporeal and extracorporeal-suturing, knot-tying using prettied loop and clip-applying. ${ }^{8}$ Also, relatively cheap laparoscopic trainers have been designed for residents who wish to develop their skills at home such as box models with optical systems based on two parallel mirrors or box models using HD webcam as the camera. ${ }^{9}$ Typically, five laparoscopic exercises performed in a box trainer (ring transferring, cutting, ligating loop, intracorporeal and extracorporeal suturing) are the core of the Fundamentals of Laparoscopic Surgery (FLS) program and mandatory for board certification by the American Board of Surgery. ${ }^{10}$

The limitations of the synthetic models are that they do not teach an entire operation but only one surgical technique and the lack of objective assessment of performance as they need the presence of an expert to demonstrate the procedure and provide feedback on performance for the acquisition of the technical skills.

The organic simulators are termed as "high fidelity", because of the closer proximity to the real-life situation. The fresh-frozen human cadavers provide perfect anatomy, normal tissue consistency and a realistic operative training experience. Disadvantages of human cadavers are that they are not portable, their limited number of availability (single use), their loss of tissue fidelity, compared with live models, inability to simulate complications like bleeding, concerns for disease transmission and ethical issues.

The animal models provide realism during the operative training, give good practice in the maintenance of hemostasis and mimic complications. Contrariwise, they are expensive, have anatomical differences from the human body, are for single use, require large facilities, veterinarian staff and involve serious ethical concerns.

Harvested tissue models are perfect for training of skills that require many repetitions and provide haptic feedback. However, harvested tissue models provide the operation without perfusion, require special facilities for storage and are used only for limited procedures. ${ }^{8,11-15}$

The hybrid trainers combine virtual-reality with video-box simulation, guide on how to perform entire operation, promote team based training, provide realistic haptic feedback as actual surgery and give metrics without the need of the presence of an experienced surgeon in order to give the trainee feedback. Nonetheless, hybrid trainers are not portable and require facility, time and effort in preparation and maintenance. ${ }^{16}$

Virtual reality (VR) trainers allow the learner to interact realistically with a computer-generated environment and include additional sensory information such as sound and haptics for the provision 
of a sense of a force feedback to simulate touch. VR simulation training contributes significantly to the enhancement of key surgical competencies of residents. A pioneer work, the first to discuss a "virtual reality surgical simulator", was presented in 1993 by Satava. ${ }^{17}$

Considerable advantages of VR systems are their ability to recreate individual basic surgical skills e.g. knot-tying, suturing, dissection, moving cubicles or cutting off edges of squares or to recreate surgical skills of entire procedures along with possible procedural complications in a realistic setting with advanced graphics. They provide objective metrics on a vast majority of parameters by registering, for example, the number of hand movements required to perform one stitch or the time taken to tie an intracorporeal knot or even providing information regarding the security of the knot without the presence of a teacher, thus improving operating room performance and patient outcome.

Furthermore, modern virtual reality trainers allow surgeons to train in making the right decision. ${ }^{11,16,18,19}$

During the last years, a number of VR trainers with varying complexity for different medical fields have become commercially available. Thus, VR simulators can be incorporated into the curricula of many medical specialties such as anesthesiology, interventional radiology and ultrasonography, obstetrics and gynecology, general surgery, cardiovascular surgery, orthopedics, urology, internal medicine, emergency case, ear-nose-throat or eye surgery. ${ }^{20-23}$ A proposed mapping of the simulator parameters may help program directors and trainees to evaluate important competency domains during VR-based surgical training. ${ }^{24}$

Augmented Reality (AR) is a relatively new technology in which virtual objects are superimposed on top of real world images, producing a highly realistic visual outcome of real and virtual elements coexisting in the same environment. A great advantage compared to VR is that it can achieve higher visual realism, mixing the real environment with virtual enhancements in a way that creates viewers with a sense of virtual objects being actual parts of a real world scene.

Some of the augmented reality laparoscopic simulation approaches are

- the anatomical overlays,

- the visual pathway of the instruments,

- the realistic haptic feedbacks,

- the realistic training environment which is based on real instruments, interacting with real objects, and

- the objective assessment at the end of the performance of the trainee. The laparoscopic task is demonstrated by a video on the screen and after the trainee's performance there is an objective assessment without the need for an expert laparoscopic surgeon to observe and guide the trainee during the training.

Over the recent years, several augmented reality simulators have been developed. ${ }^{25}$ While commercially available AR simulators are rather expensive, a cheap, novel AR simulator for assessment of basic laparoscopic skills has been successfully presented. ${ }^{26}$

\section{HIGH FIDELITY OR LOW FIDELITY SIMULA- TORS?}

Simulations that present highly realistic performance characteristics, contexts, and scenarios are referred to as high-fidelity, while simulations that reduce tobe-learned skills to simpler constructs or constituent parts are referred to as low-fidelity. ${ }^{27}$

High-fidelity simulators have enjoyed increasing popularity despite costs that may approach six figures. This is justified on the basis that simulators have been shown to result in large learning gains that may transfer to actual patient care situations.

However, most commonly, learning from a simulator is compared with learning in a 'no-intervention' control group. The inherent assumption that high fidelity simulations lead to better learning is an assumption for which there is a lack of supporting evidence $^{28}$ and it has been suggested that the term may be abandoned all together ${ }^{29}$.

Furthermore, a review of 24 studies that compare learning from high-fidelity simulation (HFS) with learning from low-fidelity simulation (LFS) based on measures of clinical performance has shown that both HFS and LFS learning resulted in consistent improvements in performance in comparisons with no-intervention control groups. Yet, nearly all the studies showed no significant advantage of HFS over LFS, with average differences ranging from $1 \%$ to $2 \%{ }^{28}$

Finally, it has been shown that basic laparoscopic skills acquired with a HFS virtual reality simulator (LapVR ${ }^{\mathrm{TM}}$ ) are transferable to a standard video trainer (VT) and vice versa. Both modalities provided significant enhancement of the novices' performance. Still, training with one modality does not necessarily mean a performance equivalent to that achieved with the other modality. ${ }^{30}$ 
Therefore it is fundamental to understand the effectiveness that any type of simulation might take place in preparing learners for clinical performance and the concept of simulation fidelity must be re-cast in terms of the fundamental information processing events that underpin human performance.

\section{SIMULATION VALIDITY - METRICS}

Effective surgical simulators can be either taskspecific or unique to a particular situation or surgery. ${ }^{31}$ The simulators should have a dual role, functioning both as training and testing platforms for the evaluation of surgeons. ${ }^{11}$

Kneebone proposed four criteria for the simulation-based learning:

1. Simulations should allow sustained, deliberate practice within a safe environment, ensuring that newly acquired skills are consolidated within a defined curriculum which guarantees regular reinforcement;

2. Simulations should provide access to expert tutors when appropriate, confirming that such support fades when it is no longer needed;

3. Simulations should map onto real clinical experience, warranting that learning supports the experience gained within communities of actual practice;

4. Simulation-based learning environments should provide a supportive, motivational, and learnercentered milieu that is conducive to learning. ${ }^{32}$

The concept of validity dictates the process of evaluation of a simulator and addresses the question of whether the measurements obtained from the simulator vary with the educational construct, the simulator is intended to measure. There are five types of validities that are applicable to medical simulators:

1. Face validity is assessed informally by nonexperts and is used to determine the realism of a simulator, or whether the simulator represents what it is supposed to represent. ${ }^{33}$

2. Content validity is the assessment of the appropriateness of a simulator as a teaching modality and involves formal evaluation by experts. ${ }^{31}$

3. Construct validity is one of the most valuable and mandatory assessments of laparoscopic training techniques and modalities, confirming that they can distinguish the experienced from the inexperienced surgeon based on the performance score. ${ }^{34}$

4. Concurrent validity measures the degree to which the simulator correlates with existing performance measures of the same surgical task or procedure, e.g. by another simulator of the same type that has previously undergone validation. It is necessary to have validated metrics to use for the process of comparison otherwise concurrent validation is not possible. ${ }^{11}$

5. Predictive validity measures the degree of which the test correlates with other measures of the same type at a later time in an operating room environment, concerning outcomes that are thought to be associated with the safe and effective execution of surgical tasks and procedures. It addresses the question 'can the measured performance on the simulator predict the future performance in the operating room? ${ }^{\prime 31}$

Last but not least, it must be emphasized that every simulation curriculum must be system/simulator agnostic i.e. it must be suitable to be delivered irrespectively from the platform used. What is probably of paramount importance for trainers is that a simulator is simply a tool for delivering the curriculum, and for trainees the curriculum is the king. The most substantial part of a curriculum is feedback or debriefing. This is the crucial aspect of an objective, effective and efficient learning process. It occurs as a natural consequence of our interaction with our environment. Unfortunately, we either may miss the feedback or the delay between performance and feedback may be so large that the contiguous relationship that did in fact exist is lost, as is the opportunity for learning. Simulation affords the opportunity to the surgical trainer and trainee to augment feedback on performance and ensure that it is delivered to the trainee in a timely, salient and effective manner during training. This feedback is called metrics.

Metrics provide a detailed quantification of the results which is necessary for the feedback. Without robust metrics the simulator is at best an expensive video game and at worst an adverse outcome waiting to happen. Therefore, the simulations should illustrate the important performance characteristics of procedural skill that have metrics derived and defined from, and then benchmarked to experienced operators - i.e. level of proficiency. Screening potential candidates to identify the lowest performers, who failed to reach competence in laparoscopic tasks (8-15\%), may be beneficial in the current state of increasing laparoscopy usage in surgical practice. ${ }^{46}$

While the main function of metrics is to provide the trainee with objective and proximate feedback on their performance, they also allow the trainer 
to objectively assess the progress of the novice throughout the training process. This permits the trainer to deliver formative feedback to aid the trainee in acquiring skill. The end result of a good simulator with well-designed metrics is a training system where trainees can learn both what TO do and what NOT to do when operating on patients. In the didactic part of the curriculum, the student must be taught exactly what the error is and then should be tested to insure that they are able to identify when they make an error, before starting on the simulator. The errors must be quantified so as to be completely unambiguous. Simulation training is optimal with metric-based feedback, particularly formative trainee error assessments, proximate to their performance. In prospective, randomized studies, learners who trained to a benchmarked proficiency level on the simulator performed significantly better than learners who were traditionally trained. ${ }^{35}$

\section{DISADVANTAGES OF SIMULATION}

Simulation, by definition, attempts to recreate real situations, scenarios and procedures without the presence of a patient. Inevitably, therefore, there will be an element of unreality. Procedural skills are often broken down into component parts, and unless using a hybrid approach, a procedure simulator will offer no human interaction. In addition, any equipment malfunction during the simulation can break the immersion, and disrupt any learning that has occurred. Equipment purchase can be costly, and with rapid improvements can quickly become outdated.

Software updates and additional scenarios are often available, but often at extra cost. The risk of broken immersion here is probably the most serious, if learner perceives that what is happening is an artificial feature of the simulation, their responses will be different to those in clinical practice, potentially breaking the opportunity for transfer of training. Ingraining of poor practice may occur in the absence of adequate supervision where simulator design is poor, and this will not necessarily be reflected in the output metrics from the simulator such as total procedure time, radiation time or contrast volume. ${ }^{36,37}$ Unlearning these undesirable behaviours can be difficult. ${ }^{38}$ Additionally, skills learned on a single occasion will decay if regular practice is not maintained. ${ }^{39}$

Despite the presence of high technology, there is a substantial learning curve for both learners and facilitators. The technology itself and acquisition of debriefing skill can be daunting to educators, and if not used frequently, these skills themselves may decay. ${ }^{40}$

\section{FUTURE DIRECTIONS}

In terms of research, a future improvement should be the integration of a more efficient method for the simulation of deformable virtual objects in AR. This is of crucial importance for the implementation of training scenarios involving complex deformable geometries, similar to the procedural tasks of stateof-the-art VR trainers. Another interesting issue is to quantify and replicate the stress induced during a difficult demanding task and how it impinges on human learning and the clinical practice.

The technology of simulation continues to advance, offering devices capable of improved fidelity in virtual reality simulation, more sophisticated procedural practice and advanced patient simulators. In addition, there is a growing and enthusiastic simulation faculty, with international societies and conferences with peer reviewed publications available. The evidence base continues to grow as studies progress and many hospitals and clinics adopt simulation, and there is an active research community. Documents demonstrate a centrally driven agenda for increased adoption of simulation, with the goal of improving patient safety.

In clinical acceptance, the field of simulation in health care continues to grow. National and international organizations and consortia have been established and are creating networks to foster research and collaborative efforts. The American College of Surgeons Accredited Institutes (ACSAEI) has been a network of 77 Comprehensive and 12 Focused Accredited Education Institutes.

The use of simulation in Graduate Medical Education has evolved significantly over time, particularly during the past decade. The applications of simulation include introductory and basic technical skills, more advanced technical skills, and nontechnical skills, and simulation is gaining acceptance in high-stakes assessments. Simulation is being adopted in training curricula, particularly in undergraduate medicine and early years postgraduate training. ${ }^{41}$ Specific simulation curricula are also emerging. ${ }^{42}$

Simulation-enhanced training curriculum results with superior training outcomes in psychomotor and nontechnical skills, compared with conventional surgery training, thereafter enhancing standardiza- 
tion of advanced minimally invasive procedure training and ensuring comprehensive proficiency before exposure to patient care. ${ }^{47}$

There is also a role for experienced practitioners to use simulation, both in maintaining existing skills and practising uncommon scenarios, and potentially in continued demonstration of competence. ${ }^{43,44}$ Thus, for instance, the American Board of Internal Medicine has adopted simulation as part of its maintenance of certification.

Simulation-based training has also brought about paradigm shifts in the medical and surgical education arenas and has borne new and exciting consortia that will ensure that the scope and impact of simulation will continue to broaden. ${ }^{45}$

Equipped with this knowledge, surgery will be better able to build simulations which are optimally configured for the training and assessment of advanced procedural skills in surgery. This revolution which started in surgery, probably one of the most conservative disciplines within medicine, will change all of medicine. ${ }^{35}$ We believe that this revolution represents a paradigm shift in the way procedural based medicine will be learned and practiced.

\section{REFERENCES}

1. Cates C, Gallagher A. The future of simulation technologies for complex cardiovascular procedures. Eur Heart J 2012;33(17):2127-34.

2. Savoldelli G, Naik V, Park J, et al. Value of debriefing during simulated crisis management: oral versus video-assisted oral feedback. Anesthesiology 2006;105:279-85.

3. Goddard A, Hodgson H, Newbery N. Impact of EWTD on patient: doctor ratios and working practices for junior doctors in England and Wales 2009. Clin Med 2010;10:330-5.

4. Department of Health. A framework for technology enhanced learning. London; 2011.

5. Davoudi M, Colt H. Bronchoscopy simulation: a brief review. Adv Health Sci Educ Theory Pract 2009;14(2):287-96.

6. Dunkin B. Surgical simulation centers as educational homes for practicing surgeons. Surg Clin N Am 2015;95:801-12.

7. Palter V, Grantcharov T. Simulation in surgical education. CMAJ 2010;182:1191-6.

8. Hammoud M, Nuthalapaty F, Goepfert A, et al. To the point: medical education review of the role of simulators in surgical training. Am J Obstet Gynecol 2008;199:338-43.

9. Walczak D, Piotrowski P, Jędrzejczyk A, et al. A laparoscopic simulator - maybe it is worth making it yourself. Wideochir Inne Tech Malo Inwazyjne 2014;9:380-6.

10. Fried G, Feldman L, Vassiliou M, et al. Proving the value of simulation in laparoscopic surgery. Ann Surg 2004;240:518-25.

11. Munro M. Surgical simulation: where have we come from? Where are we now? Where are we going? Journal Minim Invasive Gynecol 2012;19:272-83.

12. Aggarwal R, Grantcharov T, Darzi A. Framework for systematic training and assessment of technical skills. J Am Coll Surg 2007;204:697-705.

13. Stefanidis D, Korndorffer JJ, Heniford B, et al. Limited feedback and video tutorials optimize learning and resource utilization during laparoscopic simulator training. Surgery 2007;142:202-6.

14. Grantcharov T, Bardram L, Funch-Jensen P, et al. Impact of hand dominance, gender, and experience with computer games on performance in virtual reality laparoscopy. Surg Endosc 2003;17:1082-5.

15. Yiannakopoulou E, Nikiteas N, Perrea D, et al. Virtual reality simulators and training in laparoscopic surgery. Int J Surg. 2015;13:60-4.

16. Halvorsen F, Elle O, Fosse E. Simulators in surgery. Minim Invasive Ther Allied Technol 2005; 14:214-23.

17. Satava R. Virtual reality surgical simulator. Surg Endosc 1993; 7:203-5.

18. Kneebone R, Nestel D, Wetzel C, et al. The human face of simulation: patient focused simulation training. Acad Med 2006;81:919-24.

19. Tavakol M, Mohagheghi M, Dennick R. Assessing the skills of surgical residents using simulation. J Surg Educ 2008;65:77-83.

20. Chalouhi GE, Bernardi V, Ville Y. Ultrasound simulators in obstetrics and gynecology: state of the art. Ultrasound Obstet Gynecol 2015;46(3):255-63.

21. Tay C, Khajuria A, Gupte C. Simulation training: A systematic review of simulation in arthroscopy and proposal of a new competency-based training framework. Int J Surg 2014;12:626-33.

22. Trehan K, Kemp C, Yang S. Simulation in cardiothoracic surgical training: where do we stand? J Thorac Cardiovasc Surg 2014;147:18-24.

23. Brewin J, Ahmed K, Challacombe B. An update and review of simulation in urological training. Int Jof Surg 2014;12:103-8.

24. Loukas C, Nikiteas N, Kanakis M, et al. Deconstructing laparoscopic competence in a virtual reality simulation environment. Surgery 2011;149(6):750-60.

25. Botden S, de Hingh Z, Jakimowicz J. Suturing training in Augmented Reality: gaining proficiency in suturing skills faster. Surg Endosc 2009;23:2131-7.

26. Lahanas V, Loukas C, Smailis N, et al. A novel augmented reality simulator for skills assessment 
in minimal invasive surgery. Surgical Endoscopy 2014;29(8):2224-34.

27. Grierson L. Information processing, specificity of practice, and the transfer of learning: considerations for reconsidering fidelity. Adv Health Sci Educ Theory Pract 2014;19(2):281-9.

28. Norman G, Dore K, Grierson L. The minimal relationship between simulation fidelity and transfer of learning. Med Educ 2012;46(7):636-47.

29. Hamstra S, Brydges R, Hatala R, et al. Reconsidering fidelity in simulation-based training. Acad Med 2014;89(3):387-92.

30. Loukas C, Nikiteas N, Schizas D, et al. A head-tohead comparison between virtual reality and physical reality simulation training for basic skills acquisition. Surg Endosc 2012;26(9):2550-8.

31. Thomas G, Johns B, Marsh Jea. A review of the role of simulation in developing and assessing orthopaedic surgical skills. Iowa Orthop J 2014;34:181-9.

32. Kneebone R. Evaluating clinical simulations for learning procedural skills: a theory-based approach. Acad Med 2005;80:549-53.

33. Samia H, Khan S, Lawrence J, et al. Simulation and its role in training. Clin Colon Rectal Surg 2013;26:47-55.

34.McDougall E, Corica F, Boker J, et al. Construct validity testing of a laparoscopic surgical simulator. J Am Coll Surg 2006;202:779-87.

35. Gallagher G, O'Sullivan G. Fundamentals of surgical simulation principles and practices. London: Springer-Verlag, 2012.

36. Rader S, AU, Jorgensen E, Bech B, et al. Association between endovascular performance in a simulated setting and in the catheterization laboratory. Simul Heal 2014;9:241-8.

37. Jensen U, Jensen J, Olivecrona G, et al. The role of a simulator-based course in coronary angiography on performance in real life cath lab. BMC Med Educ 2014; $14: 49$.

38. Cawthorn T, Nickel C, O’Reilly M, et al. Develop- ment and evaluation of methodologies for teaching focused cardiac ultrasound skills to medical students. J Am Soc Echocardiogr 2014;27:302-9.

39. Dulohery M, Stoven S, Kurklinsky A, et al. Ultrasound for internal medicine physicians: the future of the physical examination. J Ultrasound Med 2014;33:1005-1011.

40. Berkowitz L, Peyre S, Johnson N. Mobilizing faculty for simulation. Obstet Gynecol 2011;118:161-3.

41. Green S, Klein A, Pancholy S, et al. The current state of medical simulation in interventional cardiology: a clinical document from the Society for Cardiovascular Angiography and Intervention's (SCAI) Simulation Committee. Catheter Cardiovasc Interv 2014;83:37-46.

42. Binstadt E, Walls R, White B, et al. A comprehensive medical simulation education curriculum for emergency medicine residents. Ann Emerg Med 2007;49:495-504.

43.Lanzer P, Prechelt L. Expanding the base for teaching of percutaneous coronary interventions: the explicit approach. Catheter Cardiovasc Interv 2011;77:372-80.

44. Lipner R, Messenger J, Kangilaski R, et al. A technical and cognitive skills evaluation of performance in interventional cardiology procedures using medical simulation. Simul Heal 2010;5:65-74.

45. Willis R, Van Sickle K. Current status of simulationbased training in graduate medical education. Surg Clin N Am 2015;95:767-79.

46. Louridas M, Szasz P, Fecso A, et al. Practice does not always make perfect: need for selection curricula in modern surgical training. Surg Endosc 2017Apr 27. doi: 10.1007/s00464-017-5572-3.

47.Zevin B, Dedy N, Bonrath E, et al. Comprehensive simulation-enhanced training curriculum for an advanced minimally invasive procedure: a randomized controlled trial. Surg Obes Relat Dis 2016 Dec 2. pii: S1550-7289(16)30838-3. doi:10.1016/j. soard.2016.11.019. 


\title{
Стремление к улучшению медицинского образования: симуляцион- ный подход
}

\author{
Борис Е. Сакакушев ${ }^{1}$, Благой И. Маринов ${ }^{2,4}$, Пенка П. Стефанова ${ }^{1}$, Стефан Ст. Костянев ${ }^{2}$, \\ Евангелос К. Георгиу ${ }^{3,4}$ \\ ${ }^{1}$ Кафедра пропедевтики хирургических заболеваний, Факультет медицины, Медицинский университет - Пловдив, Плов- \\ див, Болгария \\ ${ }^{2}$ Кафедра патофизиологии, Факультет медицины, Медицинский университет - Пловдив, Пловдив, Болгария \\ 3 Лаборатория медицинской физики симуляционного центра, Факультет медицины, Афинский университет, Афины, \\ Греция \\ ${ }^{4}$ Медицинский симуляционный центр, Медицинский университет - Пловдив, Пловдив, Болгария
}

\section{Адрес для корреспонденции: \\ Борис Е. Сакакушев, Кафедра пропедевтики хирургических заболеваний, Факультет медицины, Медицинский университет - Пловдив, бул. „Пещерско шосе" 66, 4002, Пловдив, Болгария E-mail: bsakakushev@gmail.com Tel: +359889716672 \\ Благой И. Маринов, Кафедра патофизиологии, Факультет медицины, Медицинский университет - Пловдив, бул. „Васил Априлов" 15A, 4002 Пловдив, Болгария \\ E-mail: bmarinov@pathophysio- logy.info \\ Tel: +359887567798}

Дата получения: 23 марта 2017 Дата приемки: 18 апреля 2017 Дата онлайн публикации: 24 апреля 2017

Дата публикации: 27 июня 2017

Ключевые слова: медицинская симуляция, обучение на основе симуляции

\section{Образец цитирования:}

Sakakushev BE, Marinov BI, Stefanova PP, Kostianev SS, Georgiou EK. Striving for better medical education: the simulation approach.

Folia Medica 2017;59(2);123-131. doi: 10.1515/folmed-2017-0039
В последнее время отмечается стремительное распространение медицинской симуляции, вызванное развитием технологий, сокращением времени обучения и повышенной процедурной сложностью. Симуляционное обучение ставит перед собой цель повысить уровень безопасности пациента на базе улучшения технической компетентности и устранения человеческого фактора в среде без риска. Она имеет особо важное значение применительно к практическим, процедурно-ориентированным специальностям.

Симуляция может быть полезной для начинающих обучаемых, опытных клиницистов (например для ревалидации) и тимбилдинга. Симуляция превратилась в краеугольный камень обеспечения медицинского образования, ввиду изменения парадигмы образования и обучения врачей. Симуляции должна быть отведена активная позиция в становлении учебной программы на основании показателей, принятия определения сравнительного анализа умений и не должна зависеть от использованных симуляционных платформ.

В дополнение следует отметить некоторые недостатки. В отсутствие компетентного руководства возможно приобретение плохих навыков. В дополнение, любая неисправность оборудования в ходе симуляции может повлиять негативно на качество протекающего учебного процесса. Независимо от наличия высокотехнологического оборудования, наличествует существенная кривая обучения как для обучаемых, так и для посредников.

Симуляционная технология продолжает усовершенствоваться, предлагая устройства с улучшенными характеристиками симуляции виртуальной реальности, с более сложной процедурной практикой и усовершенствованными манекенами. Обучение, базированное на симуляции, тоже вызвало изменение парадигмы пространства медицинского и хирургического образования и создаёт уверенность, что охват и роль симуляции продолжит расширяться. 